\title{
The Relation Between Shoppers and Different Designs of Commercial Spaces; a Humanistic Approach, Irbid City as a Case Study
}

\author{
Samia Ayyoub Salim Ayyoub \\ Department of Architecture Engineering, Hijjawi Faculty for Engineering Technology, Yarmouk University, Irbid 21163, \\ Jordan
}

Corresponding Author Email: samia.ayyoub@yu.edu.jo

https://doi.org/10.18280/ijsdp.150412

Received: 31 October 2019

Accepted: 16 March 2020

\section{Keywords:}

economic conditions, humanistic, pedestrian mall. rational use, sustainable

\section{INTRODUCTION}

In Jordanian cities, the old downtowns are considered a unique historic link with the past, as it reminds us of their social and economic growth through time. Despite the downtowns unorganized nature and underdeveloped infrastructure, its heritage value is in the fact that it's a living breathing monument to the life style that once dominated the Jordanian cities and a vibrant place for generations to meet and experience the city's history personally. However, even with the downtown's vast importance in the collective memory of the city dwellers and the heritage it symbolizes, it is still ignored and unattended by the authorities.

It is important to carry the traditional fabric into the future, to ensure its continued importance to the city's residents' daily lives, through upgrading it to ensure the community's involvement and to keep serving the society's economic and cultural needs without sacrificing its history.
The downtown has always had an important place in the city's economy as it was the center of trade and job creation, as well as a major tourist attraction in many cities, each bosting a unique experience and features deepening the city's identity within its residents and visitors alike. A city's downtown represents the heart and soul of the community, a public melting pot where all different members of the population can meet, as such, gauging its health can be an indicator of the quality of life, pride and wellbeing of the community.

Within the numerous issues and problems that plague Jordanian downtowns, taking Irbid city as the focus of this study, this paper will focus on the inhospitality of the downtown at this current age to visitors and residents due to a number of reasons which this paper will try to resolve though suggesting urban solutions and building regulations, such solutions would answer these symptoms when implemented and increase Irbid's downtown attractiveness for residents and visitors. 


\section{SHOPPING}

Shopping is an important part of our lives because it is how we obtain the things we need such as food, clothes, shoes and the like. It is a necessary and an ordinary activity. And although the primary activity in shopping is to get the goods required for our daily use, the word 'shopping' could also encompass eating and drinking in cafes, going to places of interest, being with one's friends as well as visiting shops and simply walking around. As Kristina Bäckström once said "Shopping is also a form of leisure opportunities" [1].

Tuber Edward identified a range of personal and social reasons for shopping, "such as diversion from the routine daily life, self- satisfaction, learning about new trends and ideas, sensory stimulation, social experiences and physical activity with friends as well as the pleasure of haggling" [2].

Shopping is also identified by two additional stimulations: choice optimization (i.e. searching for and finding exactly what one wants); and the probable use of a product more recently, Campbell suggesting that the pleasure derived from the freedom of 'just looking' and the pleasure of physical experience are important motives [2]. Shopping has become a consumer's habitant $[3,4]$.

There are six purposes for shoppers: enjoying the aesthetics, escaping from routine and boredom, exploring new products or stores, engaging in a state of absorption, gaining new information about stores and products, also as social interaction and relationships. The shoppers enjoyed spending time in a sensory/novelty-rich environment. This environment offered potential for separation and escape for these participants. Also, people do not know what they want until you show it to them.

\section{METHODOLOGY}

This paper relied on several surveys conducted over the last three years that focused on different characteristics of the city's fabric and built environment. Using the Geographic Information Systems software (GIS), the different data collected on the city was combined to create a singular data base, this allowed a more holistic view of the city's downtown, as well as the analysis of the different issues that concern this paper.

The GIS software's ability to combine survey data with geographic maps and compose visual representations enabled the conduction of a spatial analysis to the downtown area.

As this study focuses primarily on the unique urban planning of Irbid city downtown, and the opportunities hidden within this uniqueness, the research reviews many works which have laid out the base for such situations and uses them as guidelines to shape the scenarios proposed by this study.

The paper continues to demonstrate the effects of its suggestions by conducting a comparison between the proposed scenario - which applies the theories and guidelines of the reviewed literature on an accurate reconstruction of the downtown enabled by the GIS software - and the case of the current situation.

Concluding the research with a set of recommendations and regulations that can facilitate the proposed scenario into reality.

\section{IRBID CITY}

Irbid is located to the north of the Hashemite Kingdom of
Jordan. It is considered one of the most beautiful cities in the Kingdom and is nicknamed "The bride of the north" for its beauty. It is located 80 kilometers $(\mathrm{km})$ to the north of the capital Amman. With an area of about 1.572 square kilometers it holds a Population of 1.77 million inhabitants (2015) [5].

In the past few decades, Irbid city has witnessed excessive urban growth rates associated with the large increase in its population. Due to its unique geographic location, Irbid has become an important commercial and administrative center in the north of Jordan; the city's center attracts all kinds of commercial activities, serving the population of the larger city, nearby towns and more than 300 villages surrounding it. The downtown also provides an urban space in which social, economic and cultural practices operate at different levels.

\section{DOWNTOWN OVERVIEW}

Downtown centers are multifunctional: they offer more for the local community than only shopping opportunities - town centers are widely seen as places that improve and develop the local economy as well as the social life of the community.

Jane Jacobs was among the first urban thinkers who recognized this role of town centers. In her classic article 'Downtown is for people' (1958), which has inspired her bestseller "The Death and Life of Great American Cities" (1961), she states that the blend of offers and the opportunity to come together in a public space, has turned the downtown into a 'living room' for the local community [6]. Coca said that downtown centers are multifunctional social places [6]. So, it is clear that to build or redesign the downtown you have to observe how the people use it in order to know how to develop it the right way. Because good walking paths and comfortable street furniture makes people feel well. An attractive downtown center is like a party where people stay because they are enjoying themselves [7-9].

Irbid, being the central nod for about 300 surrounding villages, is considered the commercial and governmental center for its region. But by observing the road map of Irbid downtown, (Figure 1). It is noted that most of the main streets that connect Irbid with the surrounding villages go through the city's downtown. With these streets being the main link between Irbid and these surrounding villages, they have become exceedingly crowded as a result of heavy traffic, street side car parking and a narrow pedestrian path.

The analyses of the city's organizational scheme showed that it has not grown in an organized manner, on the contrary it grew without any urban planning [10]. The streets were narrow and bending, the houses and shops close together, (Figure 2).

The commercial center of the city, which contains all the main markets, public buildings, banks, and offices, is about 3 square kilometers $\left(\mathrm{km}^{2}\right)$, which is about 8 Percent $(8 \%)$ of the total city's area. $64 \%$ of the buildings have commercial uses, $17 \%$ are residential, and $19 \%$ are of mixed use (residential and commercial) [11]. The unexpected growth of the population and the uncontrolled, unplanned urban expansion, in addition to the reliance on individual vehicle transportation forms, have produced an excessive pressure on the city's urban infrastructure, which demands better and urgent development of the city's urban planning.

In the first field survey of the city, completed in the 1910's, the boundaries of the plots were set according to the existing buildings with its organic shapes. The areas of the plots vary according to the area of the existing buildings (Figure 3) 
creating deformed organic plots most of them with an area no more than 50-100 square meters $\left(\mathrm{m}^{2}\right)$ [11] (Table 1 and Figure $4)$.

The greatest number of buildings in Irbid city appear to be from about 1870-1930 when most of the public, institutional and commercial buildings and large private houses were erected.

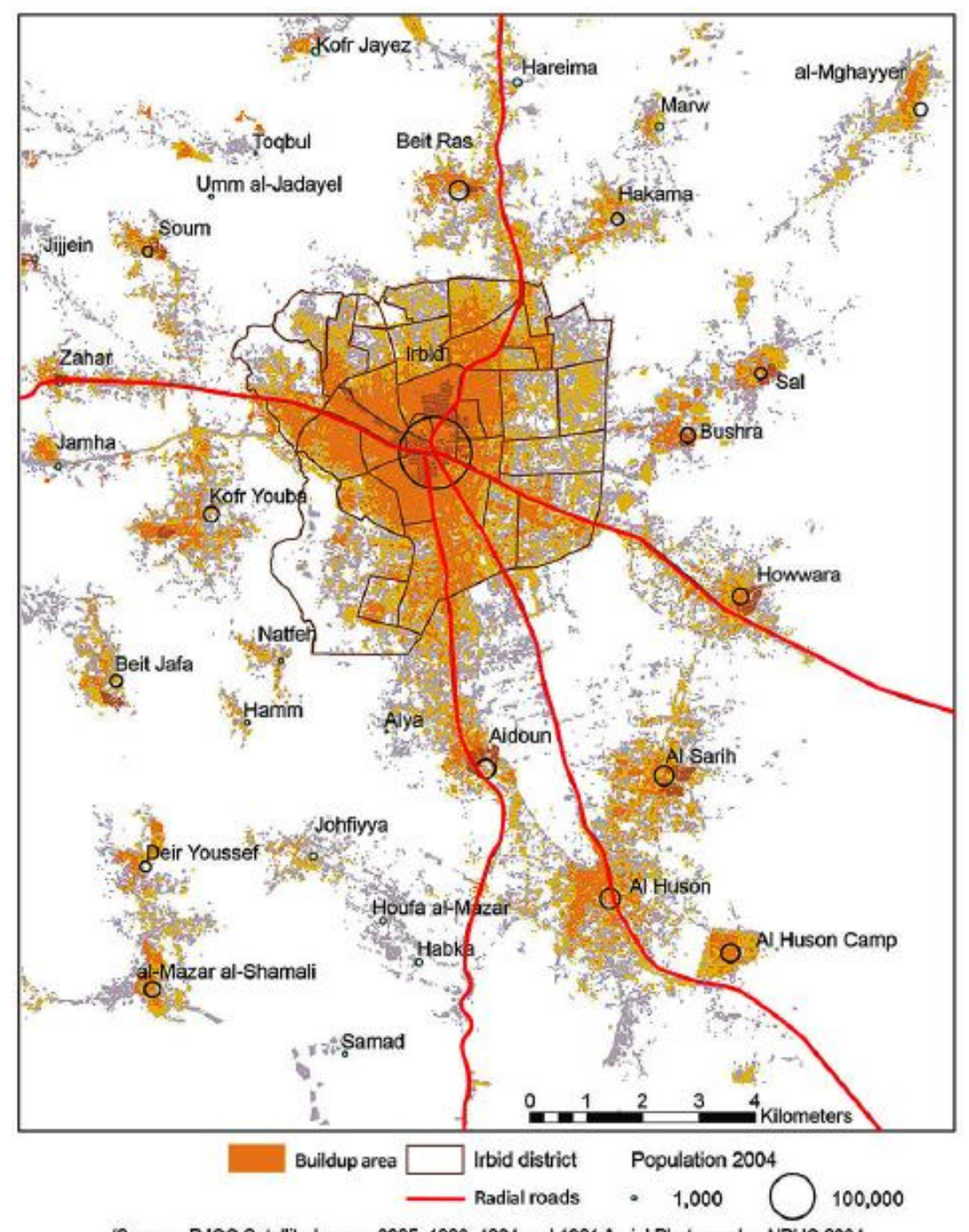

(Scurce: RJGC Satellite Images 2005, 1996, 1984 and 1961 Aerial Photographs. NPHC 2004 Conception: Ababsa. Design: RJGC and Ababsa, Ifpo, 2009)

Figure 1. Irbid city with the surrounding villages

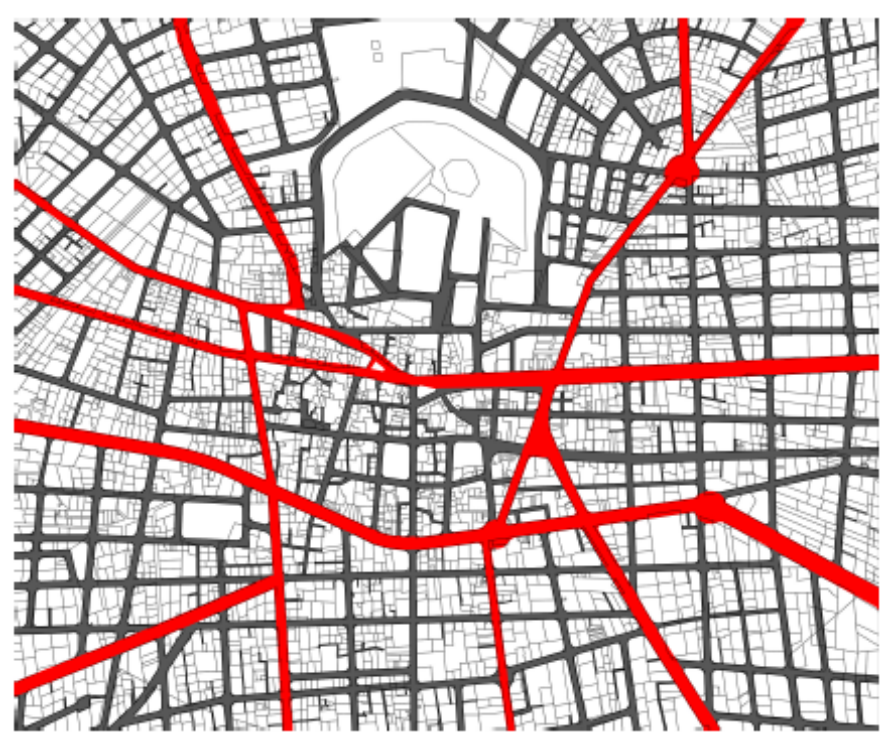

Figure 2. The radial main streets in the city downtown 


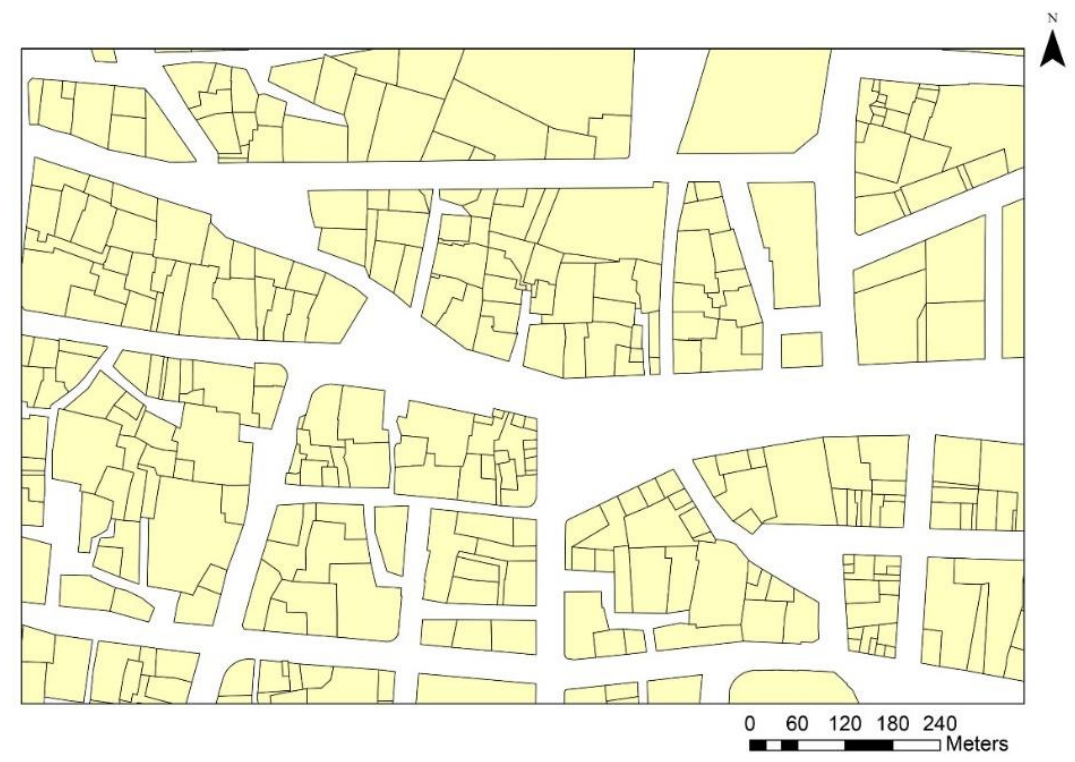

Figure 3. A sample of land plots

Table 1. Downtown areas and number of plots

\begin{tabular}{ccccc}
\hline Plot's area $\left(\mathbf{m}^{\mathbf{2}}\right)$ & Sum of area $\left.\mathbf{( m}^{\mathbf{2}}\right)$ & \% of the downtown area & Number of Plots & \% of the downtown Plots \\
\hline$<100$ & 18853 & $11 \%$ & 375 & $40 \%$ \\
$100-200$ & 42431 & $25 \%$ & 288 & $30 \%$ \\
$200-300$ & 37642 & $22 \%$ & 152 & $16 \%$ \\
$300-400$ & 14856 & $9 \%$ & 44 & $5 \%$ \\
$400-500$ & 12295 & $7 \%$ & 28 & $3 \%$ \\
$500-600$ & 45913 & $27 \%$ & 54 & $6 \%$ \\
Total area $\left(\mathrm{m}^{2}\right)$ & 1.71 .990 & & 941 plots & \\
\hline
\end{tabular}

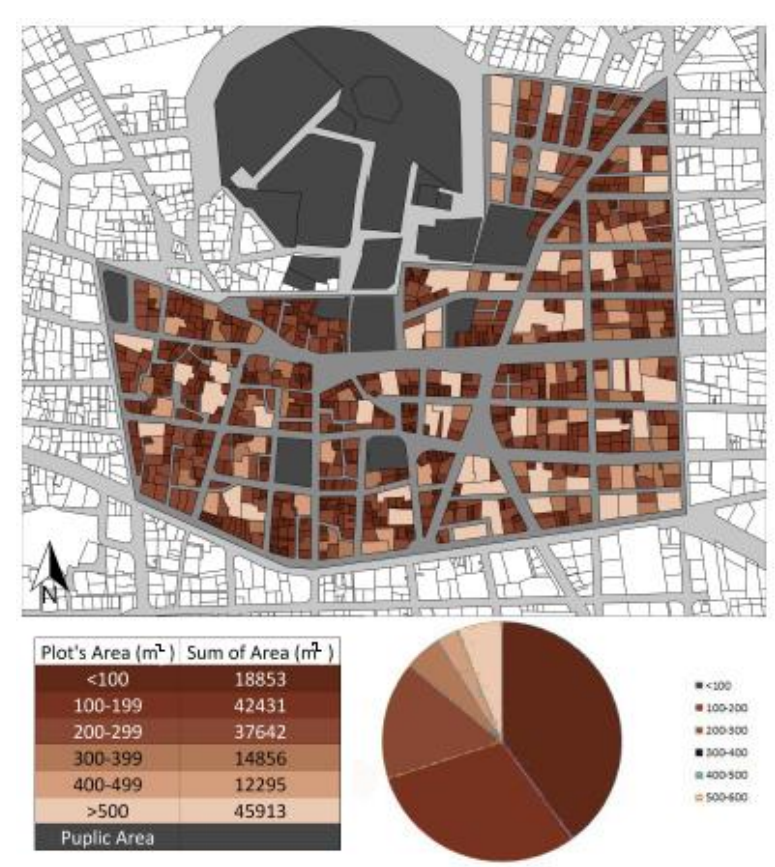

Figure 4. Areas of downtown plots

The following are some additional information provided by the survey that has been carried out in this area.

- The majority of buildings were constructed before $1950.76 \%$ of the buildings in the implementation area are classified as old.

- $62 \%$ of those buildings, which consist of one to two floors at most, are in poor to fair conditions, mostly concerning structure and maintenance.

$40 \%$ of the buildings' areas are too small, about 10 to $20 \mathrm{~m}^{2}$. And the small area of the plots will not make it possible to construct new buildings.

The small area of the plots stopped in the way of a lot of development and rebuilding because the development needed to reuse the plots with more than one floor. Spaces for vertical circulation, elevators, staircases, and such were needed. Therefore, most of the buildings are still used with the old structure and as one floor small shops entered from the street. Not to mention that a lot of the shops cannot be rebuilt, because they are considered part of the city's heritage and thus the owners had to keep doing maintenance for these building over time. The following Figure 5 explains some information about the existing buildings in Irbid downtown.

To understand the problems faced by pedestrians and shoppers and to comprehend the concept of pedestrian friendliness in Irbid city downtown and how to creat a pedestrian friendly environment, as well as to develope an appreciation of the position and the importance of the pedestrian in the development of the economic center of Irbid downtown.

The following will be a description of the two typologies of shopping experiences; the stores which open directly to a street, and the stores which open to a plaza (the pedestrian mall). 

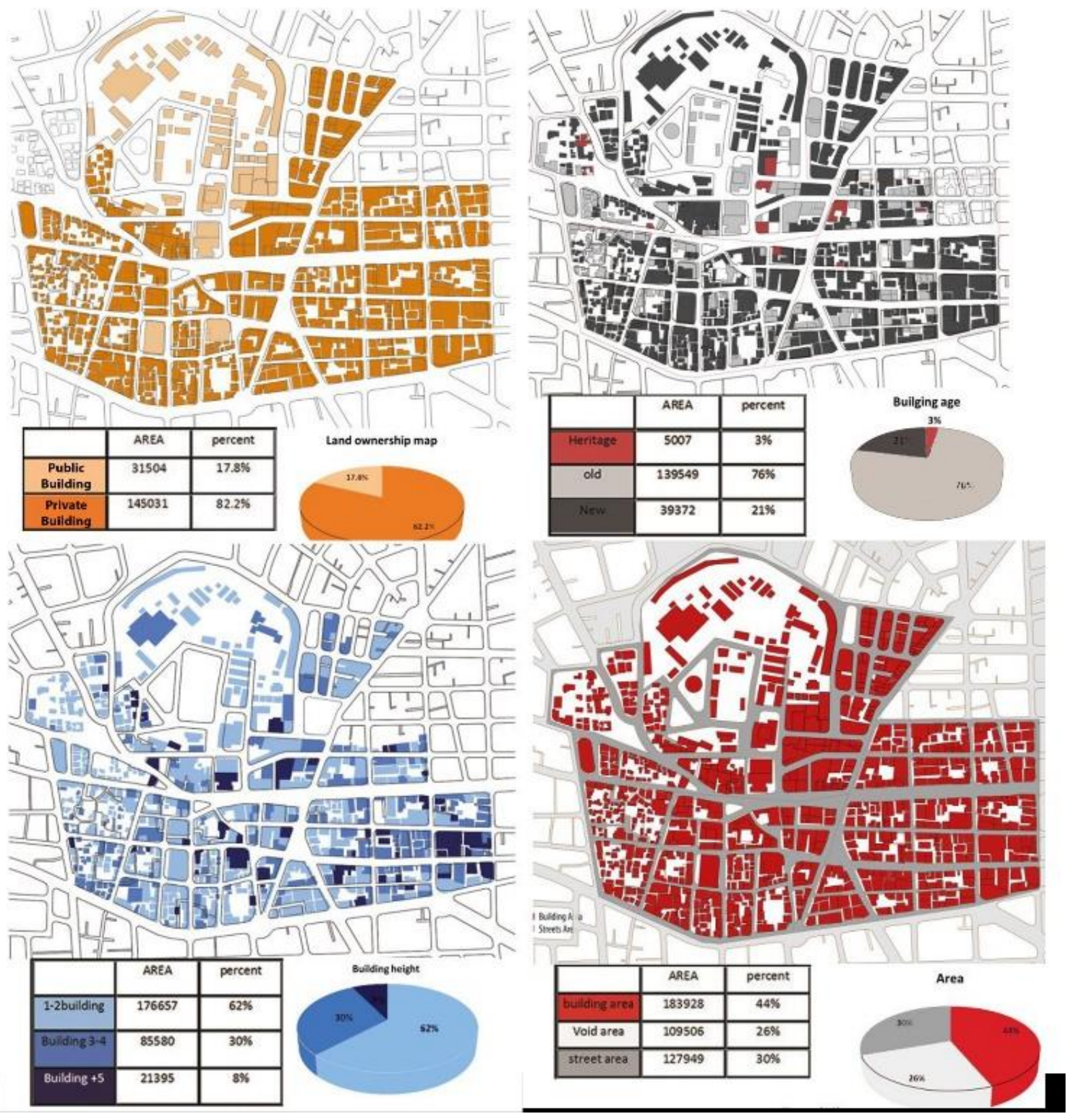

Figure 5. The survey data of Irbid downtown

\section{FIRST TYPOLOGY; SHOPPING STORES OPENED DIRECTLY TO THE STREET (SSODS)}

By Considering Irbid's history and the organic layout of the city's growth, the commercial spaces are concentrated in the city's Centre where all the main streets interconnect and radiate into the surrounding villages. Most of Irbid's commercial land use is organized as a linear double sided storefront along main streets. This typology for commercial spaces was very effective for the shop owners since it provided them with great exposure. However, when the automobile was introduced those streets became shared between the pedestrian shoppers and the traffic of cars coming from the villages or simply city residents commuting to or from work. The cars took most of the space, followed by parking spaces to access the various shops, leaving the pedestrians (who are the main users of the market space) with only a marginal sidewalk, which continuously gets over run by shop owners who extend their shops by displaying their goods on the sidewalk, resulting in blocking the passage of the pedestrians and forcing them, sometimes to step onto the street.

Having heavy traffic streets pass through the middle of a busy market space proved to be a dangerous situation, as pedestrians and cars frequently crossed into each other's paths, making the shopping experience a life hazard in a noisy and a polluted environment. This has caused many shoppers to disdain from entering the downtown area, considering it a chore rather than a pleasant trip, and a space unfitting for families and elder people to experience.

An extra factor to consider is the lack of an architectural theme or regulations to govern this chaotic space, resulting in the shopper's complaint about the lack of aesthetics.

All the buildings in the downtown used to be an attached building with no set back from the street side and a good setback from the back side. This layout caused inner courtyards to spawn in the middle of commercial blocks, which were occasionally used for storage or unofficial car parking areas but were mostly neglected and used as a rubbish collection area (Figure 6 and Figure 7). 


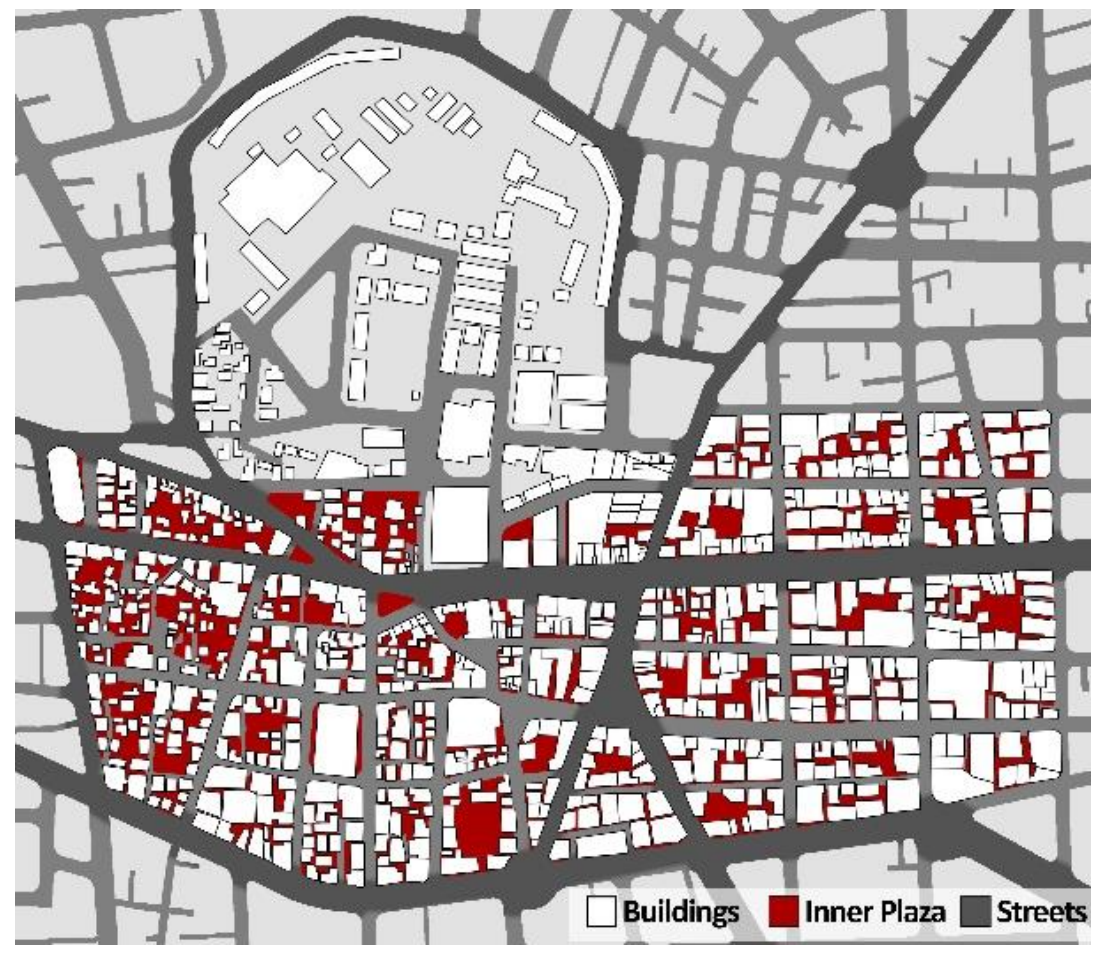

Figure 6. Inner court yards or plazas

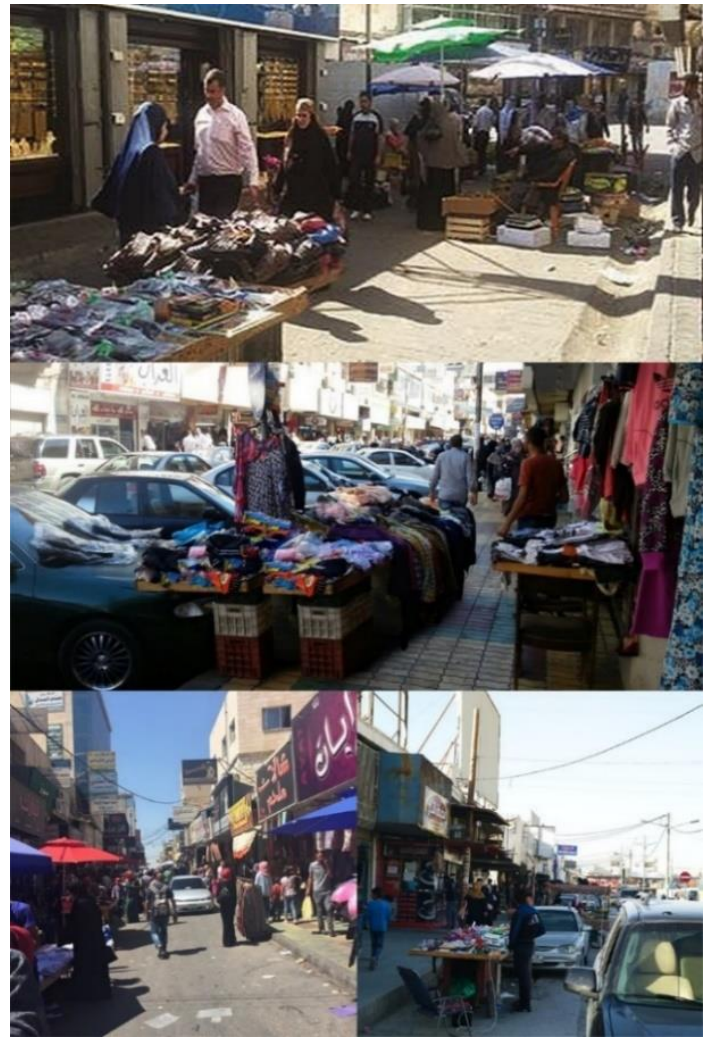

Figure 7. The crowded streets in Irbid city's center

\section{SECOND TYPOLOGY; SHOPPING STORES OPENED DIRECTLY TO PLAZA. (SSODP)}

The pedestrian mall is a downtown corridor - usually a few linear blocks along the traditional main shopping street where the pedestrians are physically separated from motor vehicles and where pedestrian transportation is given highest priority. Usually, the vehicles' movements through these streets are controlled, only allowed during specific, limited, and pre-arranged periods of time for the sole purpose of providing the retail stores with goods and other necessities. But in the case of Irbid city downtown, most of the streets are arterial; therefore, it would have been difficult to stop the running of vehicles through these streets. One option was to attempt the construction of a bridge or a tunnel to help redirect the traffic away from the pedestrians, but, unfortunately, the width of these streets has created some difficulties and limitations in the face of this solution.

Another, more feasible option is to have shops with two storefronts [12]. one that opens directly to the street and another that opens onto an internal plaza, where all the shops can displays their goods inside and in front of the store to the plaza area and where the shoppers can walk around all the stores in the plaza without being exposed to any vehicle accidents from the streets [13].

Separation of high-speed traffic movement from pedestrian traffic is obviously necessary [14]. Apart from safety, the shops opened to the plaza offered a comfortable and a controlled outdoor area as well as the freedom from traffic noise and inclement weather. The covered street, the arcade, also offers comfortable seating and rest areas in the wellmaintained common area, which is provided as meeting places for shoppers in addition to coffee shops and fast food establishments which meet the physiological needs of those who are hungry and thirsty.

"One of the most important elements of city design is the square or plaza. It is possibly the most important way of designing a good setting for public and commercial buildings in cities" [15].

The square or the plaza is basically an enclosed area to hold activities in, designed to showcase its surrounding buildings to the greatest advantage. A space which has been made trafficfree then repaved, thus giving more opportunities for the pedestrians to walk around and the café owners to expand their terraces [2]. A square is important for its vitality and, therefore, also for its visual attraction. 
Table 2. Comparation between the two types of typologies

\begin{tabular}{|c|c|c|}
\hline & $\begin{array}{c}\text { First typology; shopping stores opened directly } \\
\text { to the street. (SSODS). }\end{array}$ & $\begin{array}{l}\text { Second typology; shopping stores opened directly to plaza. } \\
\text { (SSODP) }\end{array}$ \\
\hline $\begin{array}{l}\text { Pollution from } \\
\text { vehicles }\end{array}$ & $\begin{array}{l}\text { Pollution from vehicles' smoke affects the } \\
\text { exposed goods in front of the shops }\end{array}$ & $\begin{array}{l}\text { No pollution, the vehicles' smoke does not affect the exposed goods } \\
\text { in front of the shops because the goods are in the inner plaza }\end{array}$ \\
\hline Noise & More noise from vehicles & Less noise from vehicles \\
\hline $\begin{array}{c}\text { Safety \& } \\
\text { accessibility }\end{array}$ & $\begin{array}{l}\text { Unsafe for the pedestrian and the risk of accidents } \\
\text { is high especially for children }\end{array}$ & $\begin{array}{c}\text { Safe for the pedestrian, no risk of accidents because there is high } \\
\text { separation between pedestrians and vehicles }\end{array}$ \\
\hline Shopping time & $\begin{array}{l}\text { Shopping time is short because many factors drive } \\
\text { the pedestrians to leave quickly }\end{array}$ & $\begin{array}{l}\text { Shopping time is extended because time spent within the plaza is } \\
\text { more interesting and pedestrians can easily move between shops } \\
\text { without obstacles }\end{array}$ \\
\hline $\begin{array}{l}\text { Weather } \\
\text { condition }\end{array}$ & $\begin{array}{l}\text { No protection from the sun or the wind and the } \\
\text { goods are exposed for rain as well }\end{array}$ & $\begin{array}{l}\text { Shelters used within the inner plazas to protect the pedestrian from } \\
\text { sun, wind, and rain }\end{array}$ \\
\hline $\begin{array}{l}\text { Storefront } \\
\text { windows }\end{array}$ & $\begin{array}{c}\text { Due to the small size of the shops and their small } \\
\text { storefront area the owners display their good on } \\
\text { the pedestrian path creating an obstacle on the } \\
\text { path of the pedestrians. }\end{array}$ & $\begin{array}{l}\text { The shops can have two storefronts to display their good in a more } \\
\text { direct way, and they can more safely display their goods towards the } \\
\text { inner plaza }\end{array}$ \\
\hline Comfort & $\begin{array}{l}\text { An uncomfortable experience because of the small } \\
\text { pedestrian paths and the obstacles on them as well } \\
\text { as the close by car traffic }\end{array}$ & $\begin{array}{l}\text { A more comfortable experience because of the landscaped plaza and } \\
\text { the safety from car traffic }\end{array}$ \\
\hline
\end{tabular}

In comparison to shop stores opened direct to the street, the stores within the plaza are perceived as more social, considering these stores not only foster social behavior of larger groups, but also afford a pleasant social environment in which to relax, meet friends, eat and drink, sit and watch the world go by Pourjafara [16].

The market square is still considered the hub of social life and a place of great and diverse activities. The square or the plaza is for the city what the atrium represents for the family home [15].

Campbell has argued that the recreational role of modern shopping centers is nothing but an extension of the recreational role of city centers. Shopping centers differ from city centers in that all commercial and recreational facilities happen under the same roof rather than on the same street. It is the street sociability (i.e., the sharing of public places with strangers), the social order of the civilized public street that is transplanted inside the plaza [2].

How does the shopping plaza support shoppers' need for social interaction? In the classic study of urban public space, it is observed that suitable space, water (fountain and pools), plants, food stand, and shelter from the wind and the sun were associated with high activity and usage. Consistent observations indicate that the presence of open spaces, benches and food courts provides more opportunities to socialize $[17,18]$.

Table 2 summaries and compare between the two types of shopes.

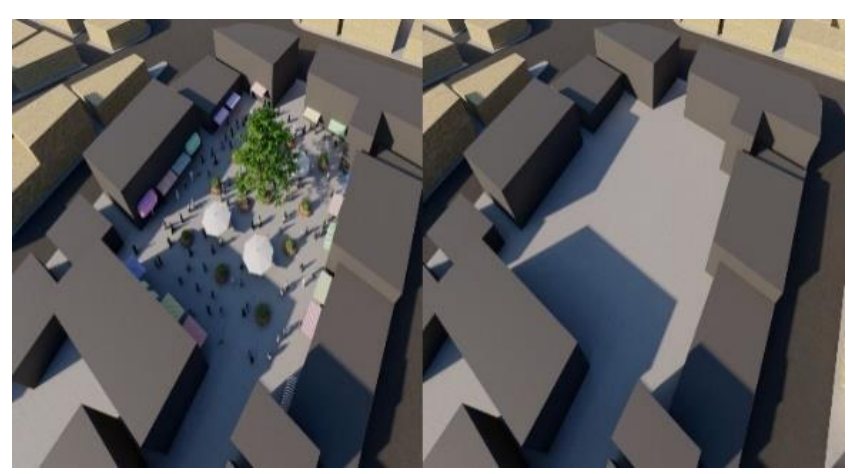

Figure 8. A redesign proposition example of one of the inner unused plazas, after and before, in the urban center
For many people, the shopping plaza offers a way to get rid of boredom through entertainment provides convenient shopping and is a safe and a free 'public' social place to meet and interact with others. So, what could compete with the mall in the future and lead to its demise? Well, back in 1984, Jacobs predicted that one possibility would be a combination of television, video games, and computers [19]. But Markham was optimistic that retailers will adapt their demands. Online shopping will most likely take a minor part of sales from traditional shopping, but pedestrian shopping malls will continue to succeed as they attract customers through the provision of more entertainment $[19,20]$ (Figure 8).

\section{SHOPPING - PLEASURE RELATIONSHIP}

For generations, people have been using the spaces offered within a city in pursuit of several daily activities and downtown city space has worked practically well for these uses up until recently [21]. Owing to the fact that when car traffic grew quickly, the competition for city space intensified and the environments for urban life and pedestrians have become less and less dignified year by year. Therefore, to strengthen the integration of the pedestrian with the city, there had to be a main priority by the urban planners and architects; to develop safe, sustainable, lively, and healthy cities. It is equally urgent to strengthen the social function of city space as a meeting place that donates toward the aims of social sustainability and an open and democratic society, where the pedestrians are invited to walk as much as possible in connection with their daily life activities with a feeling of security and a decline in noise levels around city spaces. Improvement of the city space will directly improve the people's connections with the city space, which is the main approach for achieving lively, safe, sustainable, and healthy cities.

Shopping atmosphere influences consumers' moods through the aesthetics, the easiness of movement, the feeling of safety and security, the comfortable surroundings, socializing with vendors and fellow customers, the searching and discovering of goods as well as the haggling for better prices. All those participate in the shopping experience and provide entertainment for the users. Not to mention that 
spending time with other citizens in a local space which they all identify with, helps users to grow a sense of belonging.

In addition, the retail environment has an impact on an array of consumer's emotions and attitudes: for example, the effect of crowding on the shoppers' excitement and the effect of comfortable environments on the vendors' sales.

There is theoretical support for linking pleasure with the perception of service quality. For instance, research has indicated that pleasure motivates shopping activities, encourages a shopper to stay longer and interact more with store employees [22] and in return, it improves service quality perceptions. However, shoppers in bad moods who are experiencing the current situation may wish for time to pass quickly and thus may either be less patient waiting for service or may interact less with store employees [3].

There is no doubt that shoppers who are in a good mood are more likely to want to affiliate with store employees, stay longer in the shopping environment, and make more purchases. Therefore, comfort is expected to influence service quality perception positively.

The public market is a place where a variety of goods are sold regularly by many small, private vendors, and shopping at a public market is a common practice in all societies throughout the world [23, 24].

One example of a public market is the farmers' market, which is an outdoor market where small-time farmers sell fruits and vegetables directly to the public [25]. In early years, most of the markets were set up on open lots along a major road, which later became known as the market street [25].

Then the local grocery store became general stores, specialty stores, and department stores. And in downtown, the neighborhood grocery stores offered personal services on a small scale and a friendly setting, which often became the social and news center for customers. However, the local grocery stores could not offer the variety and social opportunities of a large public market [26].

\section{THE STREET AS A SPACE}

Streets served as a marketplace, a meeting place, a waiting place, a community space, a social space and as a center of movement. Basically, a space for human interaction.

The conversions of streets into vehicle-oriented roads have dramatically influenced the quality of city space, ignored the user as a living breathing being and viewed streets as little more than a corridor for the flow of traffic.

The spirit of street life is reflective of the urban character of the area and an integral part of the urban environment. An active street goes a long way in bringing life and spirit to an area and attracting the public to come out onto it for what it offers [27]. Today, it has expanded, with some, forming a pattern with plazas and open spaces at many of the intersections. These serve as spaces to relax, usually highlighted by sculptures or historic landmarks, and provided with seating. Regardless of the scale and general monotony of the modern metropolis, there is always going to be a need for public spaces for human interaction, where a person can find himself in scale with his surroundings.

\section{CONCLUSIONS}

It all starts with an understanding of how customers (people) behave. The different but complementary look at the relationship between the physical aspects of the shopping environment and the shopping behavior taken from the shopper's perspective. It begins with the assumption that a shopper has certain needs, motives, or goals in mind, for which he later seeks out the appropriate shopping environment to achieve. A one that maximally supports those goals or needs. This proposed framework specifies that shopping environments must be designed to meet the different needs of various types of shoppers. The key is to maximize the person - environment fit.

This study provides design guidelines that can be used by municipalities or private retailers looking to revitalize retail districts through environmental improvements:

- All the shops or most of them should open a back storfornt towards the inner plaza so the shops can expose their goods, as well as have some shading devices to provide protection for the goods from sun, rain ... etc.

- The exposed goods should be protected from the dust and vehicles' smoke.

- Some cafe shops can extend their seating area into the inner plaza.

- Shoppers will be able to walk around without fear of traffic accidents.

- $\quad$ Shoppers and pedestrian will be able to spend time in an interesting landscaped plaze with some seating and shading devices and their children safe from car traffic.

- There should be connections between the plazes through specified pedestrian street crossings, so that the pedestrian paths can be more controlled to reduce the crowdness in the main streets.

The results of this research will assist the city in its planning efforts for future development of the downtown area as well as to expand the walkability of the area and enhance the shopping experience while preserving the downtown center's history and it will have a role in guiding future planning and development projects. This study can also serve as a reference tool for preserving heritage buildings in similar situations.

The limitation of the solutions proposed in this paper is that some shops will face problems opening the back store front, due to structural limitations or a lack of budget for the redesign and reconstruction of the inner plaza, which needs the cooperation between the municipality, the stockholders and the shoppers to enhance the pedestrian's and the everyday quality of life.

In my previous article "The convergence between tradition and modernity and between innovative design and the history of culture- Irbid city as a case study" [28] there is a suggestion for another solution of removing the smaller buildings to be replaced by a larger commercial building with joined shares, but in case we can't remove the buildings and especially if the buildings are part of the heritage of the city, it needs to be revitalize and maintained.

It is now clear that the pedestrian shopping malls or plazas will lead the shopping business for a while and will continue to do so until a new form of shopping or the current traditional shopping street manages to find new ways to keep their shoppers and stay in business. Until that happens, the shopping plaza will continue to lead, and architecture will always be needed to support the shopping plaza's role through creating market areas that are nice, comfortable, safe, and fun places to visit. Proposed regulations will be needed in this area, that will have direct and indirect effects on the commercial, and the 
cultural and architectural norms of our country.

Town centers in crisis are therefore advised to redesign their physical environment (place) with the help of these planning principles. Because regeneration is not only about a vision on where to go. The ultimate success factor is fruitful collaboration of a wide range of public, private, and societal stakeholders (partnership) to implement the vision.

All in all, we suggest that town center revitalization is a matter of connecting people and places and developing lasting partnerships.

\section{ACKNOWLEDGMENT}

The author is indebted to the anonymous reviewers for their constructive comments, and would also like to express her sincere thanks to Muna Ma'ayah who assisted her in editing this article.

This research did not receive any specific grant from funding agencies in the public, commercial or not-for-profit sectors.

\section{REFERENCES}

[1] Backstrom, K. (2011). Shopping as leisure: An exploration of manifoldness and dynamics in consumers Shopping experiences. Journal of Retailing and Consumer Services, 18(3): 200-209. https://doi.org/10.1016/j.jretconser.2010.09.009

[2] Campbell, C., Falk, P. (1997). The Shopping Experience. London, SAGE Publication Ltd.

[3] Laroche, M., Teng, L., Michon, R., Cheb, J. (2005). Incorporating service quality into consumer mall shopping decision making: A comparison between English-Canadian consumers. Journal of Services Marketing, $\quad$ 19(3): 157-163. https://doi.org/10.1108/08876040510596830

[4] Blosh, P.H., Ridgway, N.M., Dawson, S.A. (1994). The shopping mall as consumer habitat. Journal of Retailing, 70(1): $\quad 23-42 . \quad$ https://doi.org/10.1016/00224359(94)90026-4

[5] Statistics 2015, Department of Statistics. Retrieved (2019). http://dosweb.dos.gov.jo/ar/

[6] Hospers, G.J. (2017). People, places and partnership: Exploring strategies to reutilize town centre. European Spatial Research and Policy, 24(1): 65-79. https://doi.org/10.1515/esrp-2017-0004

[7] Ergen, B. (2013). Investigation of Streets and Pedestrian Malls. İstanbul Ticaret Üniversitesi Fen Bilimleri Dergisi Y1l: 12 Say1: 23 Bahar, pp. 1-12.

[8] Gehl, J. (2010). Cities for People. Island: Island Press.

[9] Gehl, J. (2011). Life Between Buildings; Using Public Spaces, Island, Island Press.

[10] Tawalbah, M. (1982). Geography of Irbid city, Public Irbid CityLibrary.

[11] Department of Land \& Survey (2020). https://www.dls.gov.jo/ar/Pages/default.aspx

[12] Pantano, E. (2016). Engaging consumer through the storefront: evidence from integrating interactive technologies. Journal of Retailing and Consumer Services, 28: 149-154. https://doi.org/10.1016/j.jretconser.2015.09.007
[13] Hahm, Y., Yoon, H., Choi, Y. (2019). The effect of built environments on the walking and shopping behaviours of pedestrians; A study with GPS experiment in Sinchon retail district in Seoul, South Korea. Cities, 89: 1-13. https://doi.org/10.1016/j.cities.2019.01.020

[14] Pojani, D. (2015). American downtown pedestrian "malls" rise, fall and rebirth. Territorio, pp. 173-180.

[15] Moughtin, J. (2007). Urban Street and Square. UK: Architectural Press in an imprint of Elsevier. http://dx.doi.org/10.4324/9780080520278

[16] Pourjafara, M., Aminib, M., Hatami, E. (2014) Role of bazaars as a unifying factor in traditional cities of Iran, The Isfahan bazaar. Frontiers of Architectural Research, 3(1): 10-19. http://dx.doi.org/10.1016/j.foar.2013.11.001

[17] Neal, P.Z., Orum, A.M. (2009). Readings and Reflections on Public Spaces. Taylor \& Fracis, e-Library.

[18] Jose, S. (2014). The Urban Pedestrian, a Dissertation. https://www.academia.edu/29304637/Urban_Pedestrian

[19] Markham, (1998). Life online: Researching Real Experiences in Virtual Space. Walnut Creek, CA, AltaMira Press.

[20] Merji, M., Mohsen, D., Nasraoui, K. (2012). Exploratory analysis of the shopping orientation. International Journal of Marketing Studies, 4(5). http://dx.doi.org/10.5539/ijms.v4n5p1

[21] Ozuduru, B.H. (2019). An Analysis of the Framework of Urban Public Policy for Effective City Centre Development: The Planning Issues and Challenges for Turkish City Centres. In: Özdemir Sarı Ö., Özdemir S., Uzun N. (eds) Urban and Regional Planning in Turkey. The Urban Book Series. Springer, Cham, 63-82. http://dx.doi.org/10.1007/978-3-030-05773-2_4

[22] McCarville, R., Shaw, S., Ritchie, M. (2013). Shopping as Leisure: a study of avid shoppers. World Leisure Journal, 55(2): 167-178. https://doi.org/10.1080/04419057.2013.782561

[23] Kowinski, W. (1985). The Malling of America: An Inside Look at the Great Consumer Paradise. 1st, William Morrow \& Co.

[24] Langrehr, F.W. (1991). Retail shopping mall semiotics and hedonic consumption. Association for Consumer Research, 18: 428-433.

[25] Fan, C. (2003). satisfying shoppers, psychological needs; from public to cyber-mall. Journal of Environmental Psychology. 23(4): https://doi.org/10.1016/S0272-4944(02)00102-0

[26] Ahmad, H., Fazle, F., Suhard, B.M. (2018). Public Preferences toward Shopping mall interior landscape design in Kuala Lumpur, Malaysia. Urban Forestry \& Urban Greening, 30: 1-7. https://doi.org/10.1016/j.ufug.2017.12.019

[27] Lotfata, Y., Lotfata, A. (2018). Resiliency of open public space (streets) through Transferring memory "Graffiti and wall Arts in the Tehran streets". International Journal of History and Scientific Studies Research (IJHSSR), 1(3): 03-07.

[28] Ayyoub, S.A. (2019). The convergence between tradition and modernity and between innovative design and the history of culture- Irbid city as a inspection. International Journal of Recent Technology and Engineering (IJRTE), $8(2 \mathrm{~S} 3)$ : 1103-1108. https://doi.org/10.35940/ijrte.B1206.0782S319 